\title{
PERSEPSI MASYARAKAT DALAM PROGRAM KOTA TANPA KUMUH (KOTAKU) DI KAWASAN KELURAHAN PAHANDUT KOTA PALANGKA RAYA
}

\author{
Perception of Communities in The City Without Slum Program (KotaKu) \\ in the Pahandut Urban Area Palangka Raya City
}

\section{Arifah Mir'atul Kusnah}

\section{Riban Satia}

\section{Tanja Putra}

Universitas Muhammadiyah Palangkaraya, Palangka Raya, Kalimantan Tengah, Indonesia

email:

rifamiratul@gmail.com

\section{Kata Kunci :}

Persepsi

Masyarakat

Program

\section{Keyword :}

Perception

Society

Program

\section{Accepted}

Januari 202

\section{Published}

April 202।

\begin{abstract}
Abstrak
Penelitian ini bertujuan untuk mengetahui Persepsi Masyarakat Dalam Program Kota Tanpa Kumuh (KotaKu) di Kawasan Kelurahan Pahandut Kota Palangka Raya. Metode yang digunakan adalah kualitatif. Peneliti ingin mendeskripsikan Persepsi Masyarakat Dalam Program Kota Tanpa Kumuh (KotaKu) di Kawasan Kelurahan Pahandut Kota Palangka Raya dengan menggunakan 5 (lima) indikator kinerja yaitu Stimulation, Organization, Interpretation-evaluation, Memory, dan Recall. Sumber data terdiri dari data primer yakni hasi wawancara dengan 2 orang pejabat Kordinator Kota Bagian KotaKu dan Penjabat Perumahan dan Kawasan Permukiman dan 5 orang warga masyarakat yang mendapatkan Program KotaKu di daerah Kelurahan Pahandut, sedangkan sumber data sekunder berupa Dokumen SK wali kota Palangka Raya Nomor 188.45/I30/2016 dan data basline Kelurahan Pahandut.

Hasil penelitian menunjukan bahwa Persepsi Masyarakat Dalam Program Kota Tanpa Kumuh (KotaKu) di Kawasan Kelurahan Pahandut Kota Palangka Ray bahwa fasilitas yang diberikan kepada masyarakat tidak bisa mereka gunakan secara optimal sesuai dengan fungsinya serta kesadaran masyarakat yang kurang bahwa kekumuhan tersebut merupakan permasalahan yang harus mereka selesaikan sendiri, pemerintah hanyar sebagai alat membantu untuk menyediakan fasilitas yang mereka perlukan untuk permasalahan tersebut. Menyebabkan program ini kurang optimal meski dari pihak pemerintah sudah melakukan tugasnya dengan baik,karena impelamator dari program ini dalah masyarakat itu sendiri. Program akan dikatakan berhasil apabila fasilitas yang dibangun bisa digunakan oleh masyarakat. Saran dari peneliti memberikan sosialisasi yang rutin terhadap masyarakat,dengan tujuan untuk merubah mindset masyarakat yang menjadi permasalahan utama program ini. Tidak hanya sosialisasi seharusnya pemerintah terus menerus melakukan evaluasi dan mengingatkan agar keberfungsian ini terus berjalan oleh Kelompok Kerja.
\end{abstract}

\begin{abstract}
This study aims to determine the Community Perceptions in the City without Slums Program (KotaKu) in the Pahandut Urban Area Palangkaraya City. The method used is qualitative. The researcher wants to describe the Community Perception in the City without Slums Program (KotaKu) in the Pahandut Urban Area of Palangka Raya City by using 5 (five) performance indicators, namely Stimulation, Organization, Interpretation-evaluation, Memory, and Recall. The data source consisted of primary data, namely the results of interviews with 2 officials of the City Coordinator of the City of My City and the Acting Housing and Settlement Areas and 5 community members who received the KotaKu Program in the Pahandut Kelurahan, while the secondary data source was the SK Palangka Raya Mayor Document Number I88.45 / 130/2016 and Pahandut Village basline data.
\end{abstract}

The results showed that the Community Perception in the City without Slums Program (KotaKu) in the Pahandut Kelurahan of Palangka Raya City that the facilities provided to the community could not be used optimally in accordance with their functions and lack of public awareness that the slum was a problem they had to solve itself, the government is only a tool to help provide the facilities they need for these problems. Cause this program is less than optimal even though the government has done its job well, because the impelamator of this program is the community itself. The program will be said to be successful if the facilities built can be used by the community. Suggestions from researchers provide regular outreach to the community, with the aim to change the community mindset that is the main problem of this program. Not only socialization, the government should continue to evaluate and remind that this function continues to work by the Working Group. 


\section{PENDAHULUAN}

Menurut Undang-Undang Dasar Tahun 1945

Pasal 48 H Ayat I menyatakan bahwa: "setiap orang berhak untuk hidup sejahtera lahir dan batin, bertempat tinggal, dan mendapatkan lingkungan hidup yang baik dan sehat, serta berhak memperoleh pelayanan kesehatan”. Ayat tersebut menunjukan bahwa tinggal disebuah hunian dengan lingkungan yang layak merupakan hak dasar yang harus dijamin pemenuhannya oleh pemerintah. Kota pada umumnya berawal dari suatu permukiman kecil yang secara spasial mempunyai lokasi strategis bagi kegiatan perdagangan.

Perkembangan kota merupakan suatu proses perubahan kota dari suatu keadaan ke keadaan yang lain dalam waktu yang berbeda yang dapat dicirikan dari penduduk yang makin bertambah dan makin padat, pembangunan-pembangunannya yang semakin rapat dan wilayah terbangun terutama permukiman yang cenderung semakin luas, semakin lengkapnya fasilitas kota yang mendukung kegiatan sosial dan ekonomi kota. Fenomena permukiman kumuh banyak terjadi di berbagai wilayah, khususnya di negara berkembang. Pemukiman kumuh selalu di tandai dengan terlalu banyaknya penduduk yang tinggal di suatu wilayah tanpa memperhatikan esensi layak huni. Kelayakan ini dapat di ukur dengan adanya indikator : akses terhadap kebutuhan dasar yang cukup, sanitasi yang memadai,ketersedian air bersih, ketahanan bangunan, ruang hidup yang memadai, serta jaminan layak huni (Berner,2007). Keberadaan pemukiman kumuh ini tertentu berdampak buruk pada kesejahteraan masyarakat baik dari sisi fisik maupun psikologi.

Indonesia dalam era kepemimpinan Joko Widodo, memiliki 9 Agenda prioritas yang di kenal dengan Nawacita Presiden Jokowi, dimana dalam poin ketiga tercantum : “Membangun Indonesia dari pinggiran dengan memperkuat daerah-daerah dan desa dalam rangga kesatuan. Melalui nawacita tersebut, dapat di lihat bahwa pada ke pemimpinan Joko Widodo, akan mengusung pembangunan menyeluruh hingga pada perbatasan dan pinggiran. Hal ini lah yang kemudian mendasari pembentukan program pemerintah yang di kenal dengan nama Kota Tanpa Kumuh (KotaKu).

Program KotaKu merupakan program nasional untuk mencegah dan mengentaskan pemukiman kumuh nasional yang di sesuaikan pada pelaksanaan Rencana Strategis Direktorat Jendral Cipta Karya tahun 20I52019. Pembentukan KOTAKU bertujuan untuk pengentasan pemukiman kumuh di perkotaan hingga pedesaan, meningkatkan kualitas pemukiman, dan meningkatkan akses untuk mendapatkan pelayanan dan infrastruktur yang memadai sehingga tercapainya kesejahteraan yang berkelanjutan di 100 kabupaten/kota di seluruh Indonesia. Namun fakta secara umum menunjukan bahwa penduduk pemukiman kumuh selalu mengalami peningkata sekitar 10\% pertahun. Sehingga penting di lakukan upaya pengetasan pemukiman kumuh. Indonesia merupakan salah satu Negara berkembang yang memiliki visi yakni berperan aktif dalam pembangunan daerah guna menciptakan pemerataan kesejahteraan penduduk yang salah satu nya di wujud nyatakan dengan ada nya kelayakan huni dalam masyarakat. Hal yang sering terjadi adalah tingkat kebutuhan rumah tinggal yang tidak seimbang dengan tingkat kemampuan kota dalam penyediaan prasarana dan sarana pemukiman yang terjangkau dan layak huni karena keterbatasan lahan kota. Akibatnya adalah suatu kawasan permukiman akan menerima beban yang melebihi kemampuan daya dukung lingkungannya dan cenderung menjadi kumuh.

Beberapa kota besar di Indonesia seperti Jakarta, Surabaya, dan Semarang berdasarkan hasil penelitian Bank Dunia (1993) menyimpulkan bahwa pertambahan penduduk yang tinggi ternyata dibarengi 
dengan menaiknya jumlah permukiman kumuh dan liar dengan kondisi lingkungan yang sangat memprihatinkan. Hal yang sama ini ditemui di kota seperti Banjarmasin, dan Palangka Raya yaitu permukiman padat, menunjukan kondisi lingkungan yang cukup memprihatinkan.

Permasalahan permukiman cenderung timbul sebagai konsentrasi dari proses pertumbuhan dan perkembangan kota (urbanisasi) yang tidak seimbang antara kemampuan daya dukung kota terhadap kebutuhan penduduknya. Pertumbuhan penduduk yang tinggi mendorong perkembangan kota yang cepat pula, namun kenyataan ini tidak dibarengi dengan kenaikan tingkat padatnya penduduk secara merata. Masih banyak penduduk kota yang berada pada golongan rendah. Kondisi demikian berdampak pada ketidakmampuan masyarakat kecil untuk membeli lahan di kota untuk tempat tinggal sebagai akibat tingginya harga lahan.

Infrastruktur juga memegang peranan penting sebagai salah satu roda penggerak pertumbuhan ekonomi yang tidak terpisahkan dari ketersediaan infrastruktur seperti transportasi, telekomunikasi, sanitasi, dan energy. Meningkatnya jumlah penduduk di perkotaan yang berlebihan juga akan menyebabkan naiknya kebutuhan penyediaan sarana dan prasarana permukiman. Kondisi ini terutama terjadi karena adanya pertambahan aktivitas kota dalam kegiatan sosialekonomi dan pergerakan arus transportasi. Tingkat kepadatan penduduk menjadi semakin tinggi, berjalan seiring dengan tuntutan kebutuhan akan rumah tinggal.

Di Kota Palangka Raya sendiri, masih terdapat banyak kawasan yang masuk kategori kawasan kumuh. Salah satunya di Kecamatan Pahandut yang terbagi dalam beberapa titik Danau Seha, Murdjani, Rindang Banua, Mendawai dan pahandut seberang. Dampak lain yang ditimbulkan dari persoalan itu kawasan permukiman akan menerima beban melebihi kemampuan daya dukung lingkungan.
Inilah yang kemudian menjadikan wilayah cenderung menjadi kumuh. Pemerintah Kota Palangka Raya pun berkomitmen dalam memperbaiki pembangunan berbagai infrastruktur dan pemberdayaan bagi masyarakat. Infrastruktur yang dibangun dalam rangka mendukung pelaksanaan program penanganan kumuh perkotaan dan membangun sanitasi masyarakat dalam peningkatan kualitas hidup sehat. Semua itu bagian dari program Kota Tanpa Kumuh (KotaKu).

Hadirnya program kota tanpa kumuh (KotaKu) yang dilaksakan pada tahun 2016, perubahan dalam struktur pembangunan menjadi lebih baik, serta layak huni dengan adanya pembangunan seperti jalan Beton Induk, Jalan Titian Beton, Drainase, Ruang Terbuka Hijau, dan Bank Sampah dan terjalinnya silaturahmi antara warga dengan baik.

Menurut CSU's Urban Studies Dapartemen, kawasan kumuh merupakan suatu wilayah yang memiliki kondisi lingkungan yang buruk, kotor, penduduk yang padat serta keterbatasan ruang (untuk ventilasi cahaya, udara, sanitasi, dan lapangan terbuka) (Hariyanto, 2007). Kondisi yang ada sering kali menimbulkan dampak yang membahayakan kehidupan manusia (misalnya kebakaran dan kriminalitas) sebagai akibat kombinasi berbagai factor. Di Kalimantan Tengah khususnya kota Palangka Raya yang sedang berkembang, tentu perkembangan itu secara umum akan meningkatkan pertumbuhan penduduk yang cukup pesat, seiring pertumbuhan itu harus di barengi dengan fasilitas untuk memenuhi kebutuhn masyarakat itu sendiri terkhususnya pada bidang fasilitas fisik, saranan dan infrastruktur.

Kebutuhan itu harus di penuhi agar tidak menimbulkan kawasan kumuh yang terjadi pada kotakota yang berkembang dan besar pada umumnya. Menurut Kepala Dinas Cipta Karaya Rojikinoor melalui Sekertarisnya Sobirin Muchtar, ada 5 kawasan kota yang termasuk dalam katagori kawasan kumuh yaitu Danau 
Seha, Murjani Bawah atau Rindang Banua, Mendawai dan Pahandut Seberang. Dan Kelurahan Pahandut, Langkai, Pahandut Seberang, dan Tumbang Rungan, menurut SK Wali Kota Palangka Raya Nomor 188.45/I30/2016 semua masuk dalam kategori Kelurahan Kumuh, tambahnya (Andika,2016).

Kawasan Kelurahan Pahandut ini sudah cukup tua di Palangka Raya mulai tahun 1982 sudah ada pemukiman di kawasan murjani bawah ini. Luas wilayah murjani bawah 486,69 ha dan 31,75 ha tergolong kawasan jumuh dengan kepadatan penduduk 9.432 jiwa, adapun bangunan rumah tergolong kumuh 2.489 unit. $\mathrm{Di}$ dalam Profil itu sendiri terdapat 3 kawasan pemukiman kumuh yaitu, komplek Mendawai, Murjani Bawah dan Danau Seha dari ketiga lokasi tersebut Murjani Bawah yang termasuk dalam kategori kumuh berat, yang memiliki permasalahan utama yaitu, Kepadatan, Sanitasi, Jalan dan Persampahan.

Program Kota Tanpa Kumuh (KotaKu) yang akan diturunkan ke pemerintah daerah sebagai kebijakan itu Kondisi kumuh yang ada di Kawasan Kelurahan Pahandut ini terjadi karena perilaku masyarakat yang membuang sampah, sebelum adanya program ini masyarakat lebih sering membuang sampah dibawah jembatan atau dibawah kolong rumah, hal ini lah yang menjadikan kondisi kumuh di kawasan Keluraan Pahandut dan hal ini terus menerus terjadi, sampai sebelum adanya program itu di terapkan. Munculnya program KOTAKU di kota Palangka raya pada tahun 2016 menjadi pendukung dalam terwujudnya pemukiman perkotaan yang layak huni, produktif, dan berkelanjutan. Yang dipimpin oleh Pemerintah dan berkolaborasi dengan pemangku kepentingan dalam perancanaan maupun implementasi dengan mengikut sertakan masyarakat dalam menjalankan program tersebut, sebagai program yang mampu menanggulangi kemiskinan dan pemukiman kumuh di perkotaan.

\section{METODOLOGI}

Jenis penelitian ini menggunakan deskriptif kualitatif yaitu Penelitian yang mengumpulkan data berupa kata, kalimat, skema dan gambar, (Sugiono, 2017:1). Penulis berusaha mengetahui gelajala-gejala yang terjadi pada objek penelitian yang berlangsung pada waktu tertentu dan kemudian menggambarkan kejadiankejadian dengan data yang di dapat dari hasil pengamatan dan penelitian di lapangan. Untuk itu penulis menggunakan teknik pengumpulan data yaitu melalui observasi, wawancara, dan dokumentasi.

Dalam proses wawancara, penulis menggunakan 5 (lima) Indikator Persepsi yaitu Stimulation, Organization, Interpretation-evaluation, Memory, dan Recall, (Lilieweri 2011:157).Sumber data primer dalam penelitian ini adalah I orang Pejabat Dinas Perumahan dan Kawasan Permukiman Kota Palangka Raya, I orang penjabat Kordinator Kota bagian KotaKu dan 5 orang warga masyarakat yang tinggal di Kawasan Kelurahan Kota Palangka Raya. Sedangkan data sekunder dalam penelitian ini adalah beberapa dokumen seperti Dokumen Surat Keterangan Wali Kota Palangka Raya Nomor 188.45//30/2016 dan data basline Kelurahan Pahandut.

\section{HASIL DAN PEMBAHASAN}

Untuk mengukur Persepsi Masyarakat Dalam Program Kota Tanpa Kumuh (KotaKu) di Kawasan Kelurahan Pahandut Kota Palangka Raya penulis menggunakan indikkator persepsi, yaitu dengan Stimulation, Organization, Interpretation-evaluation, Memory, dan Recall.

\section{Faktor Internal}

\section{a. Stimulation}

Berdasarkan hasil wawancara dengan anggota Kordinator Kota bagian KotaKu bahwa program Kota Tanpa Kumuh di terapkan pada tahun 2016 sesuai dengan Surat Keputusan walikota Palangka Raya Nomor 188.45/I30/20I6 diberbagai daerah yang 
ditetapkan sebagai status kumuh. Tetapi untuk wilayah kelurahan pahandut sendiri program kota tanpa kumuh yang memberi bantuan pembangunan fasilitas hidran air bersih dan spiteng komunal masuk pada tahun 2019, sebelum tahun 2019 di kawasan kelurahan pahandut sudah ada masuk program lain yang berkaloberasi dengan program Kota Tanpa Kumuh karna strategi dasar program Kota Tanpa Kumuh mencanangkan kaloberasi kepada seluruh pelaku pembangunan dalam penanganan permukiman kumuh,seperti proram PNPM. Oleh karena itu ada sebagian masyarakat yang baru mengetahui program KotaKu pada tahun 2019 ini. Fasilitas yang dibangun oleh dana kaloberasi yaitu fasilitas jalan, fasilitas pembuangan sampah yaitu dua puluh titik tempat buang sampah berupa tong-tong sampah, satu unit motor tosa sebagai alat pembawa sampah ke Tempat Pembuangan Sementara, fasilitas air bersih berupa bor air.

Jadi pembangunan fasilitas yang murni dari dana program Kota Tanpa Kumuh tanpa ada adanya kaloberasi dengan program lain yang masuk di kawasan kelurahan pahandut itu pada tahun 2019, itu yang menyebabkan masyarakat dikelurahan pahandut baru mengetahui mengenai program Kota Tanpa Kumuh. Selain itu tidak sampainya informasi mengenai program Kota Tanpa Kumuh yang dilakukan pihak Badan Swadaya Masyarakat kepada masyarakat menyebabkan banyak masyarakat yang tidak tau mengenai program kota tanpa kumuh mereka hanya tau fasilitas yang dibangun tanpa tau dari program apa fasilitisa itu diberikan.

Dan informasi yang didapat melalui Kordinator Kota bagian KotaKu bahawa fasilitas yang diberikan sepenuhnya jadi tanggung jawab oleh masyarakat dan lembaga masyarakat yang terkait,jadi yang melaksanakan program Kota Tanpa Kumuh unsur utama pelaksanaan program adalah lurah dan perangkatnya,BKM dan perangkatnya, Tim inti perencanaan, kelompok pemanfaat dan pemeliharaan (KPP) dan relawan.

Namun berdasarkan hasil yang dilihat dari pengamatan selama ini peneliti menemukan bahwa tidak ada pengelolaan terhadap fasilitas yang telah diberikan, telah banyak fasilitas yang tergolong rusak. Dapat diartikan bahwa Kelompok Pengelolaan Pemeliharaan yang ada tidak memahami betul tugas fungsinya sendiri serta kurangnya respon masyarakat untuk membayar dana iuran dengan alsan faktor ekomoni yang kurang,hal tersebut mengakibatkan kas kelompok pemanfaat dan pemeliharaan (KPP) kosong.

Berdasarkan hasil penelitian mengenai persepsi masyarakat terhadap program KotaKu dikelurahan Pahandutdari segi Stimulation dapat dilihat dari pengetahuan masyarakat mengenai program Kotaku kurang optimal mengenai tujuan program ini, karena kurangnya pemahaman masyarakat bahwa program ini sepenuhnya dikelolah oleh masyarakat.

\section{b. Organization}

Organization merupakan salah satu indikator persepsi yang merupakan pengelompokan fasilitas yang dibangun oleh program KotaKu yang diketahui oleh masyarakat dikelurhan Pahandut.

Berdasarkan hasil penelitian mengenai Organization fasilitas yang dibangun oleh program KotaKu ternyata hanya ada sebagian masyarakat dikawasan kelurahan pahandut yang mengetahui fasilitas apa saja yang dibangun didaerah tersebut oleh program kota tanpa kumuh (KOTAKU), selebihnya banyak masyarakat yang tidak tahu mengenai apa saja fasilitas yang di bangun oleh program kota tanpa kumuh (KOTAKU).Berdasarkan surat edaran Nomor : 40/SE/DC/2016 TENTANG PEDOMAN KOTA 
TANPA KUMUH menjelaskan bahwa ada $6+1$ indikator sarana prasarana dalam program Kota Tanpa Kumuh yaitu pembangunan jalan lingkungan, drainase lingkungan,penyediaan air bersih,pengelolaan persampahan,pengelolaan air limbah,pengaman kebakaran,dan ruang terbuka hijau.

Namun berdasarkan hasil penelitian tidak semuanya dapat diberikan kepada masyarakat, karena dana program ini terbatas, selain dana yang terbatas ada permasalahan lain yaitu tidak ada lahan kosong untuk pembangun saran ruang terbuka hijau tersebut. Dikelurahan pahahandut itu pun fasilitas sarana prasarana yang di bangun pada tahun 2019 hanya ada Hidran Umun dan Spiteng komunal serta ada bantuan pengadaan gerobang sampah untuk masyarakat di sana.

\section{Gambar 4.I \\ Salah satu fasilitas yang dibangun oleh program KotaKu}

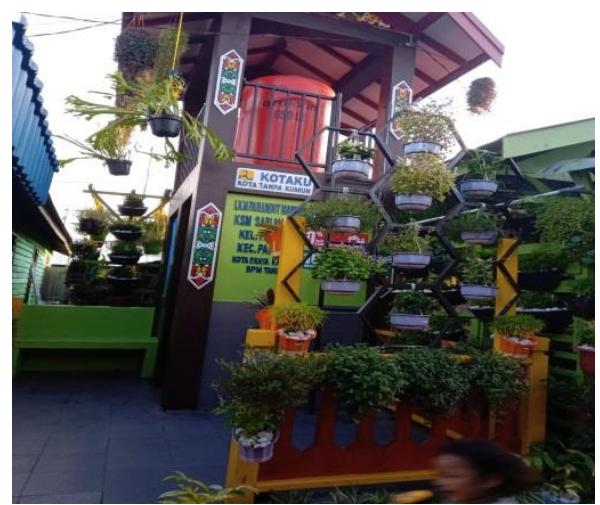

Berdasarkan hasil observasi Hampir 99\% permasalahan yang ada dikelurahan Pahandut itu adalah persampahan dan sanitasi,terkait dengan permasalahan yang ada di kelurahan pahandut tidak hanya fasilitas fisik yang dibangun tetapi diperlukan adalah kapasitibling untuk masyarakatnya sendiri itu paham bahwa itu permasalahan mereka yang harus di selesaikan oleh mereka itu sendiri (perubahan paradigm masyarakat) bahwa selama ini data bestlein itu hamper $70 \%$ - $80 \%$ persen mereka buang sampahnya di bawah rumah jadi bukan dengan cara ditanam atau di bakar.

Pengamatan yang terjadi dilapangan temuan peneliti bahwa masyarakat tidak memahami betul apa yang menjadi tujuan dari program Kotaku itu sendiri dengan masih saja membuang sampah sembarangan. Karena masyarakat disana sudah terbiasa dengan membuang sampah dibawah rumahnya masingmasing, hal ini yang telah membudaya dengan sendirinya dan budaya inilah yang berbenturan dengan standar dan tujuan dari program Kotaku, hal diatas dapat dikatakan bahwa perilaku masyarakat ini masih jauh terhadap tujuan program KotaKu yaitu penurunan angka kumuh dan tercapainya akses infrastruktu dan pelayanan dasar. Yang tidak dipahami masyarakat dari program Kotaku ini adalah setelah fasilitas yang diberikan ke masyarakat, masyarakat lah yang menjadi aktor implementasi dalam pengelolaan dan pemeliharaan fasiltas tersebut. Masyarakat masih saja berpikran bahwa program ini akan terus menerus diberikan fasilitas jika fasilitas tersebut rusak, sebenarnya tidak disini masyarakatlah yang bertanggung jawab melalui apa yaitu, Kelompok Pengelolaan, pemeliharaan yang ada didaerah kelurahan Pahandut.

Berdasarkan hasil penelitian masyarakat dikawasan kelurahan pahandut yang paham dan mengerti tujuan program Kota Tanpa Kumuh pun sedkit mereka hanya menilai bahwa program Kota tanpa Kumuh hanya untuk mengurangi kekumuhan di lingkungan mereka, padahal tujuan dari program Kota Tanpa Kumuh tidak hanya untuk mengurangi kekumuhan tetapi juga untuk meningkatkan akses terhadap infrastruktur dan pelayanan dasar di permukiman kumuh perkotaan untuk mendukung terwujudnya permukiman perkotaan yang layak huni, produktif dan berkelanjutan,sebelum tujuan tersebut 
tercapai program Kota Tanpa Kumuh harus bisa mewujudkan visi mereka yaitu 100 pemenuhan air bersih, 0 menolkan kekumuhan hunian segala macama,100 mereka memenuhi sanitasi untuk masyarakat di Kelurahan Pahandut. Tapi pada kenyataanya hal tersebut belum tercapaian secara maksimalnya karena ada nya asas prioritas mengakibatkan tidak ada pemeretaan untuk masyarakat dikelurahan pahandut serta budaya masyarakat yang masih membuang sampah dikolong rumah dan paradigma masyarakat yang berfikir bahwa program KotaKu akan memberikan lagi fasilitas apabila fasilitas tersebut rusak, sebenarnya tidak disini masyarakatlah yang bertanggung jawab atas fasilitas yang rusak melalui Kelompok Pengelolaan dan Pemeliharaan memanfaatkan iuaran dari masyarakat.

Dalam hal ini dinilai dari Organization terhadap fasilitas yang diberikan oleh program KotaKu oleh masyarakat di Kelurahan Pahandut masih kurang baik berdasarkan penelitian dilapangan bahwa masih sedikit masyarakat yang tau apa saja fasilitas yang diberikan oleh pragram ini. Serta kebiasaan masyarakat yang masih membuang sampah dikolong rumah yang masih dilakukan.

\section{c. Interpretation-evaluation}

Berdasarkan hasil penelitian dilapangan perubahan setelah adanya program Kota Tanpa Kumuh dikelurahan Pahandut belum berjalan dengan optimal jika dilihat dari visi program Kota Tanpa Kumuh yaitu mencapai 100 pemenuhan air bersih, 0 menolkan kekumuhan hunian segala macama,I00 mereka memenuhi sanitasi. Hal ini terjadi karena kesadaran masyarakat yang kurang bahwa kekumuhan tersebut merupakan permasalahan yang harus mereka selesaikan sendiri pemerintah hanyar sebagai alat membantu untuk menyediakan fasilitas yang mereka perlukan untuk permasalahan tersebut.masih ada masyarakat yang membuang sampah dikolong rumah padahal sudah disediakan tongsampah untuk meminimalisir agar masyarakat bersenti dari kebiasaan yang membuang sampah dikolong rumah.

Berdsarakan hasil observasi dilapangan fasilitas yang diberikan pun harus di gunakan sesuai fungsing masing seperti gerobak sampah digunakan untuk mengangkut sampah masyarakat tapi karena terkendala operator yang menjalakan gerobak sampah tersebut tidak ada maka prasarana gerobak sampah sempat tidak beroprasi beberapa bulan,dan juga fasilitas Hidran Umum yang harusnya digunakan untuk air minum tapi ada sebagian masyarakat menggunakan air tersebut untuk menyiram halaman atau tanaman yang mereka pelihara,hal tersebut terjadi karena mereka beranggapan bahwa air yang ada di Hidran Umum sama dengan air yang ada dirumah mereka, standar air minum yang bersih pun mereka tidak paham karna kurang komunikasi antar masyarakat dan Badan Keswadayaan Masyarakat (BKM). Menurut peneliti hasil dari pengamatan ditemukan bahwa budaya masyarakat yang masih saja membuang sampah sembarangan masih saja terjadi, ini dapat diartikan bahwa seharusnya Badan Kelembagaan Masyarakat, Kelompok Swadaya Masyarakat Kelompok Pengelolaan Pemeliharaan selalu bersinergi terhadap masyarakat agar masyarakat selalu konsisten terhadap tujuan program Kotaku tersebut, tanpa disadari bahwa masyarakat juga menjadi aktor pelaksanaan dalam program Kotaku ini, dengan tidak membuang sampah sembarangan ikut melaksanakan tujuan dari program Kotaku ini. Dengan tidak membuang sampah sembarangan maka akan mengurangi kawasan tersebut menjadi semakin kumuh, ini sejalan dengan tujuan dari program Kota Tanpa Kumuh. 


\section{Gambar 4.2 \\ Sampah yang dibuang masyarakat dibawah kolong rumah}

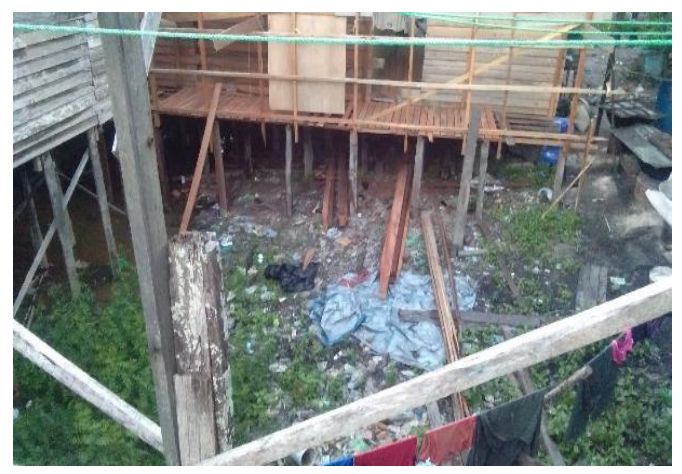

Peneliti dapat menarik benang merah bahwa program ini dapat berjalan optimal apabila masyarakat memiliki kesadaran yang tinggi bahwa masalah kekumuhan tersebut merupakan permasalahan yang harus mereka selesaikan sendiri pemerintah hanyar sebagai alat membantu untuk menyediakan fasilitas yang mereka perlukan untuk permasalahan tersebut. Merubah meinset masyarakat serta kebiasaan masyarakat yang membuang sampah dikolong rumah.

\section{d. Memory}

Berdasarkan hasil wawancara dilapangan fasilitas yang sudah dibangun sebelum digunakan oleh masyarakat kelurahan pahandut harus ada tahap serah terima fasilitas dari pihak Kordinatot Kota dengan pihak Kelompok Pengeloaan Pemeliharaan (KPP),setelah adanya tahap serah terima maka fasilitas tersebut sudah bisa digunakan tapi pada kenyataanya setelah dilakukan serah terima fasilitas kepada masyarakat, respon masyarakat kurang karena budaya masyarakat yang tidak berubah dengan membuang sampah sembarangan. Dan dari Kelompok Pengelolaan Pemeliharaan yang ada dilapangan juga tidak setiap hari dalam mengambil hasil sampah masyarakat yang ada dipembuangan sampah, sering kali sampah-sampah tersebut sampai membeludak kejalanan, maka dari itu respon dari Kelompok
Pengeloaan Pemeliharaan cukup kurang.

Namun bersadasarkan fakta dilapangan bahwa banyak sekali penolakan terhadap apa yang menjadi keputusan bersama seperti uruan untuk pengelolaan dan pemeliharaan yang telah disetujui bersama dalam kurun waktu yang lama semakin banyak masyarakat yang tidak mau bayar ini berhubungan dengan sumberdaya manusinya, kenapa dikatakan seperti itu karena alasan masyarakat yang bermacam seperti mereka tidak mau bayar karena dari segi operasionalnya yang tidak rutin sampai alasan yang cukup aneh yaitu mereka tidak buang sampah di tongtong yang disediakan maka dari itu tidak mau bayar. Urunan yang disetujui yaitu Rp 10.000 perbulan, namun harus kita sadari bahwa pekerjaan penduduk dikawasan kelurahan Pahandut dapat dikatakan hampir seluruh masyarakatnya pekerjaan nya swasta seperti, pedagang, buruh, tukang parkir dan juga banyak pengangguran.

Berdasarkan hasil observasi dilapangan respon masyarakat yang kurang ini dapat menjadi masalah bagi Kelompok Pengelolaan Pemeliharaan, karena tanpa disadari bahwa uang uranan yang ada dapat digunakan untuk pemeliharaan dan operasional, jika banyak masyarakat yang menolak tentu dari sumberdaya keuangan akan mengalami defisit, karena pada dasarnya pengeloaan dan operasional membutuhkan dana, seperti yang terjadi sekarang fasilitas seperti motor operasional yang telah rusak dan dari pihak Kelompok Pengeloaan Pemeliharaan tidak memiliki dana untuk memperbaiki nya karena banyak masyarakat yang menolak sehingga tidak terkumpulnya dana tersebut, dari segi operasional ini tidak rutin karena sulit untuk mencari orang yang iklas untuk bekerja berat dengan upah yang kecil, hal ini harus secepatnya bisa diselesaikan oleh Kelompok Pengelolaan Pemeliharaan. 
Peneliti dapat menarik benang merah bahwa pelaksanaan program dapat berjalan dengan baik apabila semua aktor pelaksana berkomitmen dari ditingkat organisasi maupun ditingkat bawah atau lapangan, serta pemahaman para aktor pelaksana terhadap tujuan pencapaian dari program hal inilah yang dapat memperkuat penyelenggaraan Program Kota Tanpa Kumuh dikota Palangka Raya khususnya kawasan pemukiman Kelurahan Pahandut dapat berjalan dengan lancar.

\section{e. Recall (pengingatan)}

Berdasarkan hasil penelitian dilapangan manfaat yang dirasakan oleh masyarakat seharusnya bisa sesuai dengan visi Kotaku yaitu mencapai 100\% pemenuhan air bersih, $0 \%$ menolkan kekumuhan hunian segala macama,100\% mereka memenuhi sanitasi,apabila fasilitas yang diberikan dijalankan sesuai dengan fungsi nya serta harus ada kesadaran dari masyarakat bahwa program ini sepenuhnya diserahkan kemasyarakat dan masyarakat bertanggung jawab penuh dalam hal pemanfaat dan pengelolaan.

Namun berdasarkan hasil observasi pada kenyataanya bahwa fasilitas yang telah diberikan tidak dapat dikelola dengan baik, masyarakat masih kurang paham bahwa fasilitas yang diberikan sepenuhnya jadi tanggung jawab oleh masyarakat dan lembaga masyarakat yang terkait, dilihat dari pengamatan selama ini bahwa tidak ada pengelolaan terhadap fasilitas yang telah diberikan, telah banyak fasilitas yang tergolong rusak. Hal ini juga yang menyebabkan tidak ada perubahan yang signifikan setelah ada nya fasilitas itu dibangun.

Dengan demikian peneliti menyimpulkan bahwa manfaat dari fasilitas yang sudah diberikan belum dirasakan oleh masyarakat belum sepenuhnya, hal ini terjadi akibat masyarakat itu sendiri yang tidak menjalankan fasilitas tersebut sesuai dengan fungsi nya dan kurangnya pemahaman bahwa masyarakat juga memiliki tanggung jawab terhadap pengelolaan fasilitas tersebut bukan hanya lembaga masyarakat terkait saja yang memiliki tanggung jawab tersebut.

\section{Faktor Eksternal}

\section{a. Interpretation-evaluation}

Tahap interpretation-evaluation ini terjadi ketika program Kota Tanpa Kumuh (KotaKu) sudah digunakan oleh masyarakat dan masyarakat itu sendiri yang memberikan penilaian terhadap program Kota Tanpa Kumuh ( KOTAKU ) terkait dengan fasilitas yang di bangun di sekitar tempat tinggal mereka dengan menggunakan komunikasii secara lisan.

Berdasarkan hasil wawancara bahwa pasti ada perubahan yang terjadi setalah adanya program Kotaku meski perubahan tersebut tidak signifikan hal tersebut disebabkan karena kurangnya pemahaman masyarakat mengenai visi dari program KotaKu itu sendiri dan kurangnya kesadaran masyarakat mengenai kekumuhan tersebut merupakan permasalahan yang harus mereka selesaikan sendiri pemerintah hanyar sebagai alat membantu untuk menyediakan fasilitas yang mereka.

Berdasarkan hasil penelitian bahwa ketika masyarakat diberikan fasilitas oleh program KotaKu mereka tidak mau mengelola dan memelihara fasilitas tersebut dengan baik, kadang ketika fasilitas tersebut rusak dibiarkan begitu saja padahal yang memiliki tanggung jawab terhadap pengelolaan dan pemeliharaan tidak hanya lembaga masyarakat terkait saja tetapi masyarakat juga memiliki tanggung jawab yang sama hal tersebut merupakan respon negativ dari masyarakat.

Berdasarkan hasil wawancara fasilitas yang dibangun oleh program ini hanya bisa di manfaatkan oleh sebagian masyarakat seperti fasilitas Hidran 
Umum yang hanya bisa dimanfaatkan oleh 20-30 Kepala Keluarga otomatis fasilitas yang dibangun masih kurang mengingat bahwa kelurahan Pahandut merupakan kawasan tersebar untuk tingkat kekumuhan. dana dari program ini juga terbatas jadi fasilitas yang dibangun oleh program KotaKu juga terbatas, maka dari itu program KotaKu sering melakukan kaloberasi dengan program-program yang memiliki tujuan untuk memengentaskan kekumuhan seperti progran PNPM. Keberhasilan suatu program jika tolak ukurnya adalah masyarakat

Disni peneliti dapat mengimpulkan bahwa keberhasilan suatu program sangat dipengaruhi masyarakat,apabila fasilitas yang diberikan oleh program ini dapat dimanfaatkan dan dikelolan sesuai dengan fungsinya maka program tersebut bisa dikatakan berhasil. Tapi pada kenyataanya dilapangan masyrakat masih kurang akan kesadaran tanggung jawab untuk mengelola fasilitas tersebut serta pemikiran masyarakat yang mengira bahwa ketika fasilitas yang diberikan rusak maka akan diberikan fasilitas lagi oleh program ini,padahal pada kenyataanya tidak.

\section{b. Memory}

Memory merupakan tahapan untuk melihat sejauh mana persepsi masyarakat tentang program KotaKu seperti dimana masyarakat menyimpan ingatan kapan mereka harus menggunakan fasilitas yang sudah diberikan oleh program Kota Tanpa Kumuh dan menggunakan fasilitas tersebut sesuai dengan persamalahan yang ada disekitar lingkungan mereka.

Berdasarkan hasil wawancara masyarakat bisa menggunakan fasilitas yang diberikan apabila pembangunan fasilitas tersebut telah selasai serta setelah ada nya tahap serah terima dari pihak KotaKu kepada anggota Kelompok Pemanfaatan dan
Pemeliharaan (KPP). Ketika tahap serah terima sudah dilakukan maka pada saat itu masyarakat juga memiliki tanggung jawab terhadap fasilitas yang diberikan untuk ikut serta menjaga dan memelihara fasilitas tersebut.

Namun dasarkan hasil observasi yang dilakukan dilapangan,peneliti mendapati bahwa ada fasilitas yang dibiarkan rusak tidak diperbaiki salah satu nya yaitu gerobak sampah yang dibiarkan mangkrak karena rusak. Hal tersebut disebabkan karena dana iuran dari warga tidak terkumpul di kas Kelompok Pemanfaatan dan Pemeliharaan (KPP) . Respon masyarakat yang kurang ini dapat menjadi masalah bagi Kelompok Pengelolaan Pemeliharaan, karena tanpa disadari bahwa uang uranan yang ada dapat digunakan untuk pemeliharaan dan operasional, jika banyak masyarakat yang menolak tentu dari sumberdaya keuangan akan mengalami defisit, karena pada dasarnya pengeloaan dan operasional membutuhkan dana, seperti yang terjadi sekarang fasilitas seperti motor operasional yang telah rusak dan dari pihak Kelompok Pengeloaan Pemeliharaan tidak memiliki dana untuk memperbaiki nya karena banyak masyarakat yang menolak segingga tidak terkumpulnya dana tersebut, dari segi operasional ini tidak rutin karena sulit untuk mencari orang yang iklas untuk bekerja berat dengan upah yang kecil, hal ini harus secepatnya bisa diselesaikan oleh Kelompok Pengelolaan Pemeliharaan.

Jadi dapat diartikan bahwa pemahaman masyarakat terhadap program ini tidak memahami betul, bahwa setelah fasilitas ini diserahkan kemasyarakat, masyarakatlah yang menjadi implementator, dan respon masyarakat ini terkesan menolak untuk mengelola serta menjaga fasilitas tersebut.

\section{c. Recall}

Tahap recall yaitu dimana pemerintah diminta untuk memberikan pendapat mengenai apa yang 
dirasakan atau manfaat yang dirasakan oleh masyarakat setelah adanya fasilitas yang diberikan oleh program KotaKu.

Berdasarkan hasil wawancara manfaat dari program KotaKu ini untuk meningkatkan kesejahteraan masyarakat yang ada dikawasan yang dinyatakan kumuh dengan meningkatkan pelayanan kawasan kumuh seperti drainase,air bersih,air minum,dan pengelolaan sampah artinya adanya perubahan lingkungan dari segi sanitasi yang dirasakan oleh masyarakat. Dengan adanya program KotaKu masyarakat juga mendapatkan sanitasi yang layak serta akses air minum yang sudah dirasakan oleh masyarakat.

Berdasarkan hasil wawancara bahwa dampak dari program KotaKu positif apabila masyarakat yang merupakan implamator pada program KotaKu ini bisa memahami tugas dan kewajiban mereka sebagai aktor utama untuk menjalankan program ini.selain itu respon masyarakat juga diperlukan agar program ini bisa menyelesaikan permasalahan kekumuhan dilingkungan mereka itu sendiri.

Namun berdasarkan fakta dilapangan tidak semua masyarakat di Kelurahan Pahandut merasakan manfaat dari program KotaKu karena masih banyak masyarakat yang tidak mau menggunakan sarana dan prasarana tersebut dengan berbagai alasan serta pengelolaan yang tidak optimal oleh pihak Kelompok Pengelolaan Pemeliharaan dalam pengoperasian sarana dan prasarana ini salah satu alasan masyarakat yang tidak mau menggunakan sarana dan prasarana tersebut, contohnya fasilitas persampahan.

Dapat diambil kesimpulan bahwa manfaat yang diinginkan dari program ini belum sepenuhnya dirasakan oleh masyarakat dikawasan Kelurahan Pahandut. Hal ini terjadi akibat berbagai hal salah satu nya adalah masih banyak masyarakat yang tidak ingin menggunakan fasilitas yang sudah diberikan serta masyarakat implamator pada program ini tidak memahami tugas dan kewajiban mereka.

\section{KESIMPULAN}

Berdasarkan dari hasil penelitian dapat diambil kesimpulan bahwa Persepsi Masyarakat dalam Program Kota Tanpa Kumuh di Kawasan Kelurahan Pahandut mereka menyambut dengan baik program KotaKu di Kelurahan Pahandut karena merasa terbantu dengan adanya fasilitas yang sudah dibangun untuk mengurangi permasalahan kekumuhan di daerah tersebut.

Namun dalam hal ini berdasarkan hasil penelitian bahwa fasilitas yang diberikan kepada masyarakat tidak bisa mereka gunakan secara optimal sesuai dengan fungsinya serta kesadaran masyarakat yang kurang bahwa kekumuhan tersebut merupakan permasalahan yang harus mereka selesaikan sendiri, pemerintah hanyar sebagai alat membantu untuk menyediakan fasilitas yang mereka perlukan untuk permasalahan tersebut. Menyebabkan program ini kurang optimal meski dari pihak pemerintah sudah melakukan tugasnya dengan baik, karena impelamator dari program ini dalah masyarakat itu sendiri. Program akan dikatakan berhasil apabila fasilitas yang dibangun bisa digunakan oleh masyarakat. Saran dari peneliti memberikan sosialisasi yang rutin terhadap masyarakat, dengan tujuan untuk merubah mindset masyarakat yang menjadi permasalahan utama program ini. Tidak hanya sosialisasi yang diberikan oleh pemerintah terhadap Kelompok Kerja, seharusnya pemerintah terus menerus melakukan evaluasi dan mengingatkan agar keberfungsian ini terus berjalan oleh Kelompok Kerja, tanpa disadari Kelompok Kerja menjadi hal penting dalam program ini. 


\section{REFERENSI}

Afifuddin. (2012). Pengantar Administrasi Pembangunan. Bandung : Alfebeta,cv

Aw Suranto. (201 I). Komunikasi Interpersonal. Yogyakarta: Graha Ilmu

Devito, Joseph, A. (1997). Ilmu Komunikasi Teori dan Praktek. Bandung: PT. Remaja Rosdakarya

Hamka. (2002). Psikologi Pendidikan. Jakarta: Rineko Cipta

Kotler, Philip. (2000). Manajemen Pemasaran. Jakarta: PT. Prenhallindo

Muhyadi. (2012). Dinamika Organisasi Konsep Dan Aplikasinya Dalam Interaksi Sosial. Yogyakarta : Ombak

Nasution,Zulkarimen. (2007). Komunikasi Pembangunan Pengenalan Teori dan Penerapannya. Jakarta : PT Raja Grafindo Persada.

P. Robbins, Stephen. (2006). Perilaku Organisasi. Jakarta:PT. Indeks Kelompok Gramedia

Rakhmad, Jamalludin. (1996). Psikologi komunikasi. Bandung: PT. Remaja Rosdakarya

Sobur, Alex. (2003). Psikologi Umum. Bandung: Pustaka Setia.

Sugihartono, dkk. (2007). Psikologi Pendidikan. Yogyakarta: UNY Press

Sugiono. (2017). Metode Penelitian Kuantitatif, Kualitatif. Bandung : Alfabeta Vc

Sukoco, Dwi Heru. (1995). Profesi Pekerjaan Sosial dan Proses Pertolonganya. Bandung : Koperasi Mahasiswa STKS Bandung

Thoha, Miftha. (2007). Perilaku Organisasi Konsep Dasar dan Aplikasi. Jakarta : PT Raja Grafindo Persada

Tjokroamidjoyo, Bibtoro. (1996). Perencanaan Pembangunan. Gunung Agung : Jakarta

Triana, Cepi. (2016). Perilaku Organisasi Dalam Pendidikan. Bandung : PT Remaja Rosdakarya

Walgito, Bimo. (2010). Pengantar Psikologi Umum. Yogyakarta : CV ANDI OFFSET

Walgito, Bimo. (1990). Pengantar Psikologi Pendidikan dengan Pendekatan Baru, Edisi Revisi. Bandung: PT. Remaja Rosdakarya

Wibhawa, Budhi. (2010). Dasar-Dasar Pekerjaan Sosial. Bandung : Widya Padjajaran.

B.Sangen Roland. (2015). Evaluasi Pembangunan Dibidang Intrastruktur Dikabupaten Kutai Timur Pasca Pemekaran Daerah. Jurnal : Magister IImu Administrasi Negara FISIP UNMUL.

Haryadi, Budi. (2016). Persepsi Masyarakat Terhadap Program Corporate Social Responsibility BI Coerner Yogyakarta.Skripsi : Universitas Islam Negrai Sunan Kalijaga Yogyakarta

Rambe, A. (2004). Alokasi Pengeluaran Rumah tangga dan Tingkat Kesejahteraan (Kasus di Kecamatan Medan,Kota Suamtra Utara). Tesis. Pacasarjana IPB, Bogor
Rosin. Analisis Tingkat Kesejahteraan Masyarakat Nelayan Didesa Daharin Selebar Kecamatan Talawi Kabupaten Batubara. Jurnal : universitas Negeri Medan.

Suhanda, Faisal. (2016). Skripsi "Peranandinas Pekerjaan Umum (Pu) Kabupaten Mesuji Dalam Pembangunan Infrastruktur Jalan

S.Priadana, Teguh. (2016). Persepsi Masyarakat Terhadap Fasilitas Publik. Skirpsi : Universitas Jember

Zulyanti, Dewi. (2017). Implementasi Program KOTAKU (Kota Tanpa Kumuh) Sebagai Model Pembangunan Infratruktur Berbasis Masyarakat Bandar Lampung. Skripsi : Universitas Islam Negeri Reden Intan Lampung. 